\title{
Team-Based Learning: Perceptions Of Instructors And Students In Thai Universities
}

\author{
Thanongsak Sovajassatakul, King Mongkut's University of Technology Thonburi, Thailand \\ Kalayanee Jitgarun, King Mongkut's University of Technology Thonburi, Thailand \\ Raveewan Shinatrakool, King Mongkut's University of Technology North Bangkok, Thailand
}

\begin{abstract}
The purpose of the study reported on in this paper was to identify and compare instructors' and students' perceptions of Team-Based Learning (TBL). Participants were 270 instructors and 288 fourth year students from the faculties of Industrial Education at six universities in Bangkok. The data were analyzed using factor analysis and structural equation modeling with LISREL $^{T M}$. Results indicated that both instructors and students agreed on the importance of two factors in TBL: Active Learning and Authentic Assessment. Students were significantly more likely to favor The Value of Team. Instructors were significantly more likely to value the importance of Instructional Design for TBL.
\end{abstract}

Keywords: Team-Based Learning; Thailand; University; Instructors; Perceptions; Students

\section{INTRODUCTION}

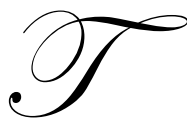

he construct of team-based learning (TBL) was originally coined, during the 1970s, by Larry Michaelsen at the University of Oklahoma (Michaelsen, Knight \& Fink, 2004). Michaelsen (2004) identified the utility of integrating group assignments in his smaller classes and therefore decided to apply the same strategy to his larger classes. Team-based learning (TBL) transforms how classroom time is used and the roles that students and teachers play in the learning process (McInerney \& Fink, 2003). It also helps students change their attitude towards responsibilities, develop human relationships from working as a team, exchange ideas, and apply knowledge to real-life situations and/or to new problems (Paulson \& Faust, 2000). As McInerney and Fink (2003) observed from their experiences with TBL, students become more motivated, develop understanding of content, and learn complex problem-solving. Most importantly, as the authors observed, TBL "promotes a learningcentered culture" (p. 3).

In 1999, the Thai government proclaimed the National Education Act (Office of Education Council, 2001), which emphasizes learner-centeredness as being at the heart of educational reform. A learner-centered approach is an approach that may yield productive teaching and learning (Office of the National Education Commission, 2002). The Act also proposes for the second decade of education reform (2009-2018) that the new generation of Higher Education (HE) students should acquire the capacity to work as a team.

However, the traditional approach to learning in Thai universities is characterized by a lack of student participation in learning, few opportunities for interpersonal relationships, and little requirement for students to seek knowledge by themselves (Polsaram, 2001). In Thailand, there has been a tradition of working individually and of following the leader (Jamornmarn, 1996). This tradition has meant that for Thai students, their ability to use team work and solve problems is very weak (Jongrungreang \& Vinijkul, 2001; Thonglert, 2007). Implementing TBL in universities, therefore, presents challenges particularly given that little is known about the use of this approach in Thailand. In addition, as Thompson et al. (2007) observed, little work has been done to identify the factors related to the implementation of TBL in general. 


\section{PURPOSE AND RESEARCH QUESTIONS}

This paper reports on a study of TBL, an approach that is inherently learner-centered, in a cultural context that traditionally has been teacher-centered. The study's focus on perceptions is an important one since, before training and education modules can be designed for TBL, it is first necessary to know how the key users of TBL perceive it. The innovative nature of TBL within the context of Thai universities or any teacher-centered context means that the issues of how both instructors and students perceive the value of this pedagogy is critical and has implications for the acceptance and use of this pedagogy by others, not only in Thailand, but in all contexts where TBL represents a fundamentally different approach to learning.

The purpose of the study reported on in this paper was to examine the differences between Thai instructors' and students' perceptions of the factors affecting TBL in universities in Thailand. The research questions guiding the study were as follows:

1. What are Thai instructors' perceptions of the factors affecting TBL in universities?

2. What are Thai students' perceptions of the factors affecting TBL in universities?

3. How do Thai instructors' perceptions differ from students' with regard to the factors affecting TBL in universities?

\section{REVIEW OF THE LITERATURE}

Studies of TBL are most common in the health sciences such as medicine and nursing (e.g., Clark, Nguyen, Bray \& Levine, 2008; Dunaway, 2005; Haidet, O’Malley, \& Richards, 2002; Hunt, Haidet, Coverdale, \& Richards, 2003; Koles, Stolfi, Borges, Nelson, Parmelee, 2010). Studies have also been conducted in management education (e.g., Fairfield, 2003), legal education (e.g., Dana, 2007), and marketing education (e.g., Hernandez, 2002). Courses such as Quantity Food Production, Meeting and Convention Sales and Service, Introduction to Tourism, Introduction to Hospitality and Tourism Management, Hospitality Management and Organization, Bistro Cooking, and Service Quality Management have used TBL techniques in classrooms in universities worldwide (Frash, Kline, \& Stahura, 2004; Kline, Frash \& Stahura, 2004; Su, 2004; Wolfe \& Gould, 2001).

Michaelsen, Knight and Fink (2004) found that the proper formation and management of groups is an essential principle of cohesive TBL. In most case these groups are determined by the instructor. The success of TBL depends on the interaction among members, group size (Aggarwal \& O'Brien, 2008), and instructor-specified objectives and guidelines on necessary advanced preparation (Sibley \& Parmelee, 2008). Therefore, a TBL instructor can be regarded as a designer or a manager (Michaelsen, 2004), or a coach (Fines, McCabe \& Sparrow, 2010). In the case of students, TBL pedagogy emphasizes the importance of pre-class preparation based upon clear learning objectives and activities (Touchet \& Coon, 2005). Students learn to take responsibility for themselves when they learn independently outside of the classroom and to take responsibility for their group when they interact with one another through activities.

TBL assessment techniques include performance evaluations, criterion-referenced appraisals, systematic observations by instructors, peer and self-assessment and portfolios (Wellington, Thomas, Powell, \& Clarke, 2002). TBL allows students to demonstrate individual and group accountability, devote their time and effort to completing group assignments, and interact with one another in productive ways. This is known as collaboration (Michaelsen, Knight, \& Fink, 2004). As Fines, McCabe and Sparrow (2010) explain, TBL is "group work on steroids." Collaboration denotes participation from all members in helping one another, and it implies facilitation among students themselves, although instructors can facilitate as needed. Over time, students show more appreciation of their team when learning through collaboration. Several studies imply a similar success of TBL during the classroom period (e.g., Hunt, Haidet, Coverdale, \& Richards, 2003). Vasan, DeFouw and Holland (2008) observed active student performance in an anatomy course, and Deeter-Schemelz, Kennedy and Ramsey (2002) also report how a learning team impacts on team effectiveness through consensus and sharing a common goal.

Sibley and Parmelee (2008) reported that TBL enables students to solve progressively more complex problems and to build bodies of knowledge that promote higher levels of understanding. Parmelee, DeStephen and 
Borges (2009) also observed that students' attitudes towards responsibilities changed as they interacted with other team members to collaborate as a team. This implies the development of interpersonal skills. These interpersonal skills can be observed in TBL for, when compared to other pedagogical approaches, only teams can provide such skills (Kelly, Haidet, Schneider, Searle, Seidel, \& Richards, 2005). Letassy, Fugate, Medina, Stroup and Britton (2008) found that a successfully implemented TBL leads to the promotion of self-directed learning as students apply knowledge to real-life situations. According to McInerney and Fink (2003), students who finish TBL lessons become more motivated, develop an understanding of content, and learn complex problem-solving skills.

\section{RESEARCH METHODOLOGY}

\section{Sample}

The sample was randomly selected and comprised 270 out of 391 instructors and 288 out of 381 fourth year students from faculties of Industrial Education in six universities in the Bangkok metropolitan area. These universities were King Mongkut's University of Technology Thonburi (28 instructors and 162 students), King Mongkut's Institute of Technology Ladkrabang (90 instructors and 37 students), King Mongkut's University of Technology North Bangkok (52 instructors), Rajamangala University of Technology Thanyaburi (43 instructors and 47 students), Rajamangala University of Technology Phra Nakorn (27 instructors and 42 students), Rajamangala University of Technology Krungthep Thailand (30 instructors).

Sixty-three percent (or $\mathrm{n}=170$ ) of instructors were male and held a bachelor's degree $(2.60 \%$ or $\mathrm{n}=7$ ), a master's degree $(69.30 \%$ or $n=187)$ and a doctoral degree $(28.10 \%$ or $n=76)$. The instructors' average age was 45 years, and they had an average of 17 years of teaching experience. Seventy-five percent of the participating students were majoring in Industrial Education and $65.30 \%$ were male. The programs in Industrial Education were civil technology education $(17.70 \%$ or $n=51)$, mechanical technology education $(22.22 \%$ or $n=64)$, production technology education ( $20.50 \%$ or $n=59)$, electrical technology education (19.10\% or $n=55)$, electronics and telecommunication technology education $(16 \%$ or $n=46)$, and computer technology education $(4.50 \%$ or $n=13)$.

The sample included no students from King Mongut's University of Technology North Bangkok and Rajamangala University of Technology Krungthep because a change in the teaching program across the country had taken place. The change meant that the students were required to take a four year course that included one year of teaching training. This newly launched curriculum in Industrial Education resulted in several universities suspending the offering of this program for some time.

\section{Measures}

The study involved the administration of a questionnaire to instructors and students. The questionnaire was developed specifically for the context of the study and contained 35 items. These items were elements of a TBL theoretical framework derived from Michaelsen (2004).

For the questionnaire, the word 'perceptions' refers to the perceptions or considered judgment of both students and instructors of the elements or components of TBL that would help the students to collaborate in learning. The questionnaire's 35 items were grouped into nine categories as follows:

1. Responsibility: instructors' gather information about the personalities of students and the errors they make.

2. Instructional Design: instructors act as both designers and managers of the learning process.

3. Authentic Assessment: instructors' use of the Individual Readiness Assurance Test ${ }_{(\mathrm{I}-\mathrm{RAT})^{*}}$ to check student knowledge.

4. Active Learning - students' build morale and encourage each other during discussions.

5. Accountability - students' devote of time and effort to include all team members when working together.

6. Facilitation - students' observe the progress of team behaviors such as greater participation during discussion.

7. The Value of Team: students' learn about the effectiveness and efficiency of TBL.

8. Knowledge Construction: students' cultivate of sustainable learning. 
9. Problem Solving: students' apply knowledge to solve problems in new and different situations in daily life by devoting time and effort while working together in teams.

Table 1: Summary Of Questionnaire Items Grouped According To Each Factor

\begin{tabular}{|l|c|}
\hline \multicolumn{1}{|c|}{ Factor } & \multicolumn{1}{c|}{ Number of Questions } \\
\hline Responsibility & 5 \\
\hline Instructional Design & 4 \\
\hline Authentic Assessment & 3 \\
\hline Active Learning & 3 \\
\hline Accountability & 4 \\
\hline Facilitation & 3 \\
\hline The Value of Team & 3 \\
\hline Knowledge Construction & 6 \\
\hline Problem Solving & 4 \\
\hline
\end{tabular}

The questionnaire used a seven-point Likert scale (Strongly Agree, Agree, Somewhat Agree, Neither Agree nor Disagree, Somewhat Disagree, Disagree, Strongly Disagree) (Warr, Cook, \& Wall, 1979) and required approximately 30 minutes to complete. The content validity was verified by five experts, based on Yaghmaie's (2003) method. The content experts consisted of five instructors in industrial technology education. All of these experts held doctoral degrees or associate professor positions. The experts were separated from the research team. Thirty instructors and 30 students were invited to test the reliability of the questionnaire. Results of the Cronbach alpha reliability coefficients of the first and the second questionnaires were 0.95 and 0.95 respectively. The index of item-objective congruence (IOC) of each item was $\geq 0.50$ (Turner \& Carlson, 2003).

\section{Procedures}

The study began with the selection of a sample. Recruitment was facilitated by the fact that researchers were Industrial Education instructors from universities in the Bangkok metropolitan area, Thailand.

Three hundred and ninety-one questionnaires for instructors were mailed to the faculties of Industrial Education in universities in the Bangkok metropolitan area, together with a document granting permission to conduct the study. Each mailing consisted of a cover letter requesting the faculty director's permission to conduct the study, copies of the questionnaire, and a time-frame reminder requesting the return of the questionnaire. A selfaddressed, stamped envelope was also included for the return of the completed questionnaire. After the deadline of twenty days, the researchers contacted the head of the faculties of Industrial Education by phone to request the return of any completed questionnaires. Sixty-nine percent of those who received the questionnaire completed and returned it.

Three hundred and eighty one questionnaires were distributed to all students who were attending their fourth year in the faculties of Industrial Education in four universities in the Bangkok metropolitan area. Students could return the questionnaire in person to one of the researchers. Seventy five percent of those who received the questionnaire completed and returned it.

\section{Data Analysis}

Data analysis began with an exploratory factor analysis by testing the adequacy of the 270 instructors and 288 students with Kaiser-Meyer-Olkin (KMO). The KMO test for measuring sampling adequacy and Barlett's test of sphericity displayed satisfactory results. The KMO value of 0.89 and 0.94 is greater than 0.5 which means the data set is likely to factor well (Kaiser, 1974). The data were first analyzed using descriptive statistics. Next, the Pearson product-moment correlation coefficient of each variable was used to show the relation matrix and to test significance. To test which method could best describe the variance and to determine the best method to extract factors, the significant variables with the factor extraction method by principal component analysis and maximum likelihood estimation was used (i.e., Gorsuch, 1983; Harman, 1976). 
The variables were analyzed using principal component analysis and factor rotation with orthogonal rotation axis (Varimax). Factors were identified by eigenvalues which are higher or equal to 1-0 and have at least three variables describing that factor with each variable having a weight value of more than 0.50 (Schene, Wijngarden, \& Koete, 1998). The interpretation of factors and their labeling with new variables required experience in labeling and in giving meaningful names to each factor by considering variables for such factors. Those involved in this step were the principal investigator and co-investigator, as well as five experts.

Structural equation modeling using LISREL ${ }^{\mathrm{TM}}$ was also relied on for the confirmatory model of instructor and student perceptions. LISREL ${ }^{\mathrm{TM}}$ is perceived as the most general method for carrying out confirmatory factor analysis (CFA) and the causal relationships among latent variables. Confirmatory factor analysis (CFA) is a tool that is used to confirm the measurement theory (Timothy, 2006).

\section{RESULTS}

A description of the factors identified as most important by instructors is presented first, and this is followed with a description of those factors identified as important by students. The results are interpreted and compared in the discussion section.

\section{Instructor Perceptions}

The factor analysis of instructors' perceptions revealed seven factors that instructors perceived through TBL as in: 1) Authentic Assessment; 2) Knowledge Construction; 3) Active Learning; 4) Instructional Design; 5) Accountability; 6) The Value of Team; and 7) Facilitation. The results could be explained $59.70 \%$ of the total variance. The results of the first-order correlation coefficients between seven factors and 26 variables (see Table 1.) were $0.56-0.81$. For the second-order correlation coefficients between the seven factors and TBL, the results were 0.52-0.87, which were at a high level as shown in Figure 1. The correlation coefficients within the seven internal factors were $0.01-0.14$, which were at a low level. It can be concluded that these seven factors affected instructor perceptions of TBL.

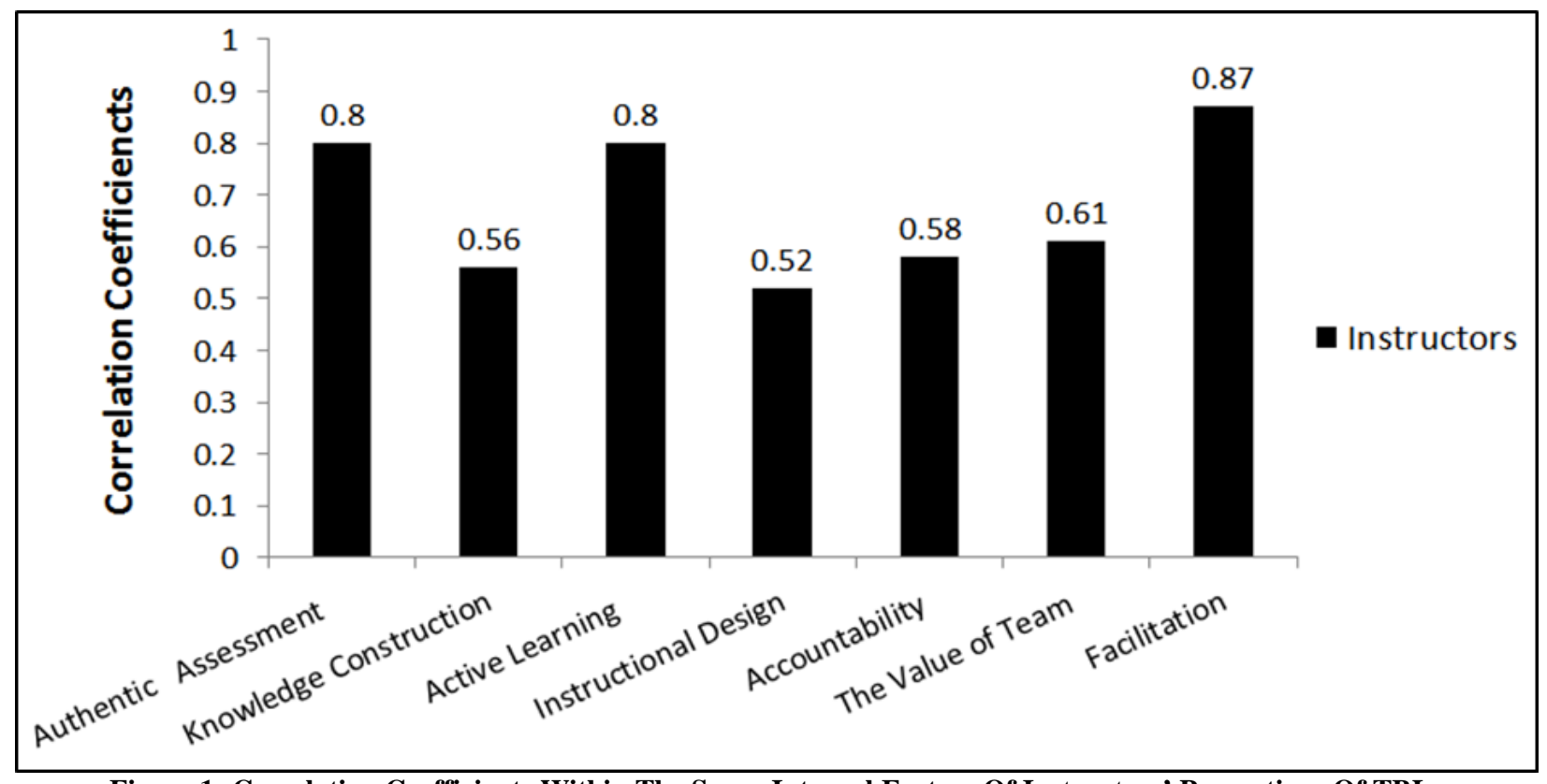

Figure 1: Correlation Coefficients Within The Seven Internal Factors Of Instructors' Perceptions Of TBL 
To confirm those seven factors already developed through factor analysis, a model modification was developed from indices using the method of Joreskog and Sorbom (1996). A model of measurement of second-order factor analysis of instructors' perceptions had highly satisfactory validity and fit the empirical data. The statistical values were as follows: $\chi^{2}$ non-significant, $\mathrm{p}=0.97$, RMSEA $=0.00$, ECVI $=2.42$, Model AIC $=603.03, \mathrm{NFI}=$ $0.99, \mathrm{CFI}=0.97, \mathrm{SRMR}=0.40, \mathrm{GFI}=0.93$ and AGFI $=0.90$. Thus, the fit indices were good which implies that the component model developed by the researchers is in accordance with the empirical data at a high level. The secondorder factor analysis had factor loadings weighted $0.58-0.89$. When the factors were ranked in terms of importance as perceived by instructors, the order was as follows: Active Learning (0.89), Accountability (0.75), The Value of Team (0.75), Facilitation (0.75), Authentic Assessment (0.66), Knowledge Construction (0.65), and Instructional Design (0.58). The results of the factor analysis and LISREL ${ }^{\mathrm{TM}}$ analysis of instructors' perceptions were then compared as shown in Table 2.

Table 2: Comparison Of The Results Of The Factor Analysis And LISREL ${ }^{\text {TM }}$ Analysis Of Instructors' Perceptions

\begin{tabular}{|l|c|c|}
\hline \multicolumn{1}{|c|}{ Factor } & Factor Analysis & LISREL $^{\text {TM }}$ Analysis $^{-1}$ \\
\hline 1. Active Learning & 0.80 & 0.89 \\
\hline 2. Accountability & 0.58 & 0.75 \\
\hline 3. The Value of Team & 0.61 & 0.75 \\
\hline 4. Facilitation & 0.87 & 0.66 \\
\hline 5. Authentic Assessment & 0.80 & 0.65 \\
\hline 6. Knowledge Construction & 0.56 & 0.58 \\
\hline 7. Instructional Design & 0.52 & \\
\hline
\end{tabular}

Table 2 revealed that seven factors resulted from factor analysis. However, using a LISREL ${ }^{\mathrm{TM}}$ analysis to confirm those seven factors, it was found that those seven factors of instructors' perceptions of TBL had good fit indices.

\section{Students' Perceptions}

The factor analysis of students' perceptions revealed six factors that affected TBL as in: 1) Active Learning; 2) Authentic Assessment; 3) The Value of Team; 4) Responsibility; 5) Problem Solving; and 6) Instructional Design. The results could be explained $61.16 \%$ of the total variance. A study of the correlation coefficients between six and 22 variables (see Table 1.) were from 0.51-0.80. For the second-order correlation coefficients between the six factors and TBL, the results were $0.52-0.79$, which were at a high level as shown in Figure 2. The correlation coefficients within the six internal factors ranged from 0.01-0.09, which were at a low level. It can be concluded that these six factors affected student perceptions of TBL.

To confirm those seven factors already developed through factor analysis, a model from modification indices was developed using the method of Joreskog and Sorbom (1996). A model of measurement of second-order factor analysis of student perceptions had high satisfactory validity and fit the empirical data. The statistical values were as follows: $\chi^{2}$ non-significant, $\mathrm{p}=0.27, \mathrm{RMSEA}=0.01, \mathrm{ECVI}=2.01$, Model AIC $=558.01, \mathrm{NFI}=0.98, \mathrm{CFI}$ $=1.00, \mathrm{SRMR}=0.04, \mathrm{GFI}=0.92$ and AGFI $=0.90$. Thus, the fit indices were good. The second-order factor analysis had factor loadings weighted 0.60-0.93. When the factors were ranked in terms of importance as perceived by students, the order was as follows: Problem Solving (0.93), Responsibility (0.92), Active Learning (0.90), Authentic Assessment (0.87), The Value of Team (0.81), and Instructional Design (0.60). The results of the factor analysis and LISREL ${ }^{\mathrm{TM}}$ analysis of students' perceptions were then compared as shown in Table 3. 


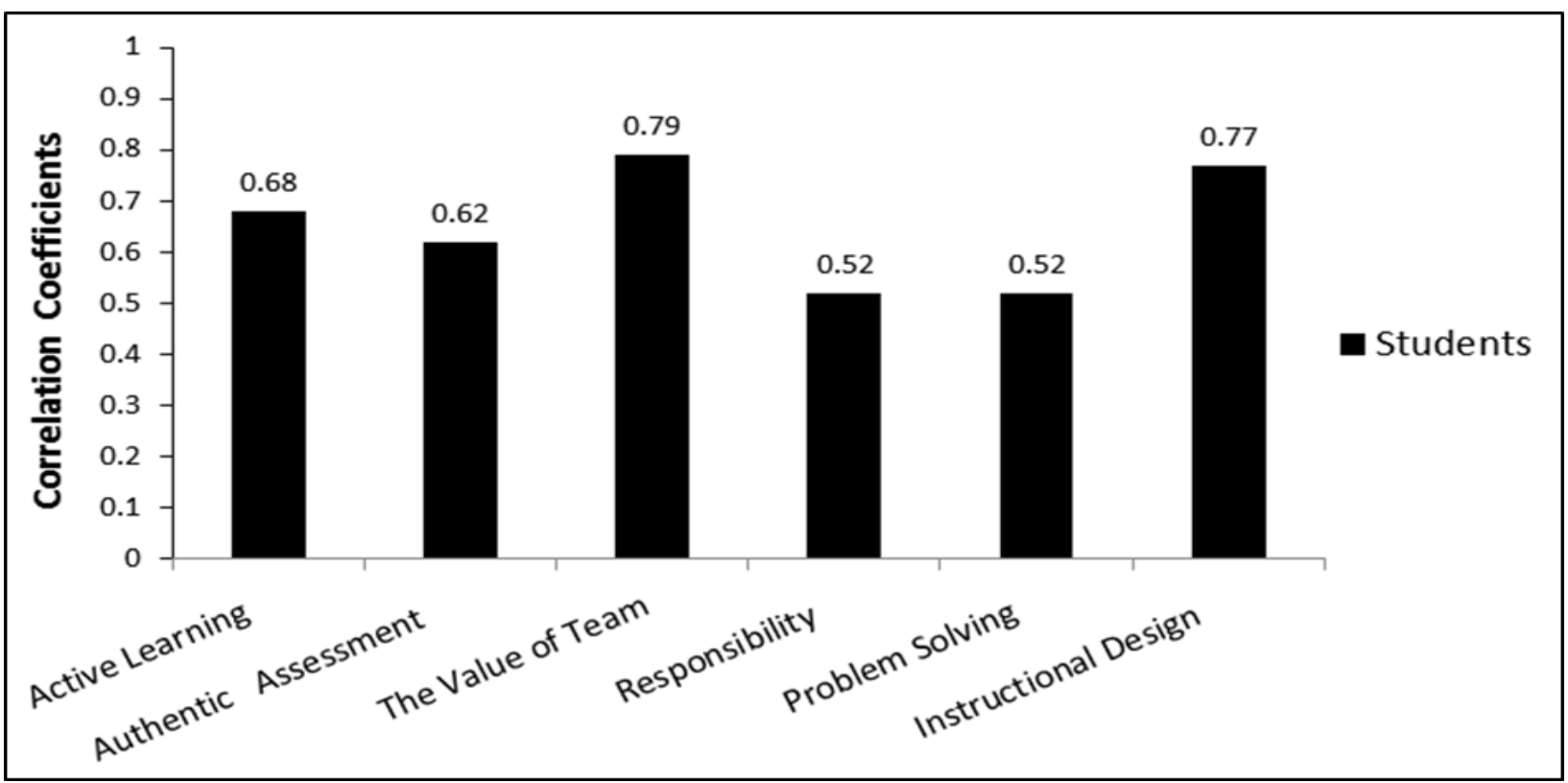

Figure 2: Correlation Coefficients Within The Six Internal Factors Of Students' Perceptions Of TBL

Table 3: Comparison Of The Results Of Factor Analysis And LISREL ${ }^{\mathrm{TM}}$ Analysis Of Students' Perceptions

\begin{tabular}{|l|c|c|}
\hline \multicolumn{1}{|c|}{ Factor } & Factor Analysis & LISREL $^{\text {TM }}$ Analysis $^{-1}$ \\
\hline 1. Problem Solving & 0.52 & 0.93 \\
\hline 2. Responsibility & 0.52 & 0.92 \\
\hline 3. Active Learning & 0.68 & 0.90 \\
\hline 4. Authentic Assessment & 0.62 & 0.87 \\
\hline 5. The Value of Team & 0.79 & 0.81 \\
\hline 6. Instructional Design & 0.77 & 0.60 \\
\hline
\end{tabular}

Table 3 revealed that there were six factors as the result of factor analysis. However, using LISREL ${ }^{\mathrm{TM}}$ analysis to confirm those six factors, it was found that only six factors of students' perceptions of TBL had good fit indices.

Table 4: Comparison Of The Factors Perceived As Important From LISREL ${ }^{\text {TM }}$ Analysis Using T-Test Between Instructors And Students

\begin{tabular}{|c|c|c|c|c|c|c|c|}
\hline Factor & Status & $\mathbf{N}^{\mathrm{a}}$ & M & SD & $\begin{array}{c}\text { Mean } \\
\text { Difference }\end{array}$ & $\mathbf{t}$ & $\mathbf{p}$ \\
\hline \multirow[t]{2}{*}{ Active Learning } & Instructors & 270 & 5.83 & 0.59 & -0.11 & -1.08 & 0.280 \\
\hline & Students & 288 & 5.94 & 0.72 & & & \\
\hline \multirow[t]{2}{*}{ The Value of Team } & Instructors & 270 & 5.78 & 0.68 & -0.14 & $-2.63 * *$ & 0.009 \\
\hline & Students & 288 & 5.92 & 0.81 & & & \\
\hline \multirow[t]{2}{*}{ Authentic Assessment } & Instructors & 270 & 5.81 & 0.68 & 0.06 & 1.45 & 0.146 \\
\hline & Students & 288 & 5.75 & 0.77 & & & \\
\hline \multirow[t]{2}{*}{ Instructional Design } & Instructors & 270 & 5.88 & 0.65 & 0.26 & $3.82 * *$ & 0.000 \\
\hline & Students & 288 & 5.62 & 0.79 & & & \\
\hline
\end{tabular}

$* * \mathrm{p}<0.01$

Table 4 shows that there were significant differences among instructors and students on their perceptions of the importance of The Value of Team and Instructional Design in TBL, $t=-2.63, p<.01$ and $t=-3.82, p<.01$, 
respectively. Students were more likely than instructors to affirm The Value of Team as important. Instructors were more likely than students than to affirm Instructional Design as important.

Figure 3 presents a chart indicating that both instructors and students perceived Active Learning and an emphasis on Authentic Assessment as important factors affecting TBL. Compared to instructors, students were significantly more likely to value The Value of Team than Instructional Design. Thus, in TBL classrooms, instructors' perceptions of student learning achievement through TBL may focus less on Instructional Design than on The Value of Team or Active Learning or Authentic Assessment.

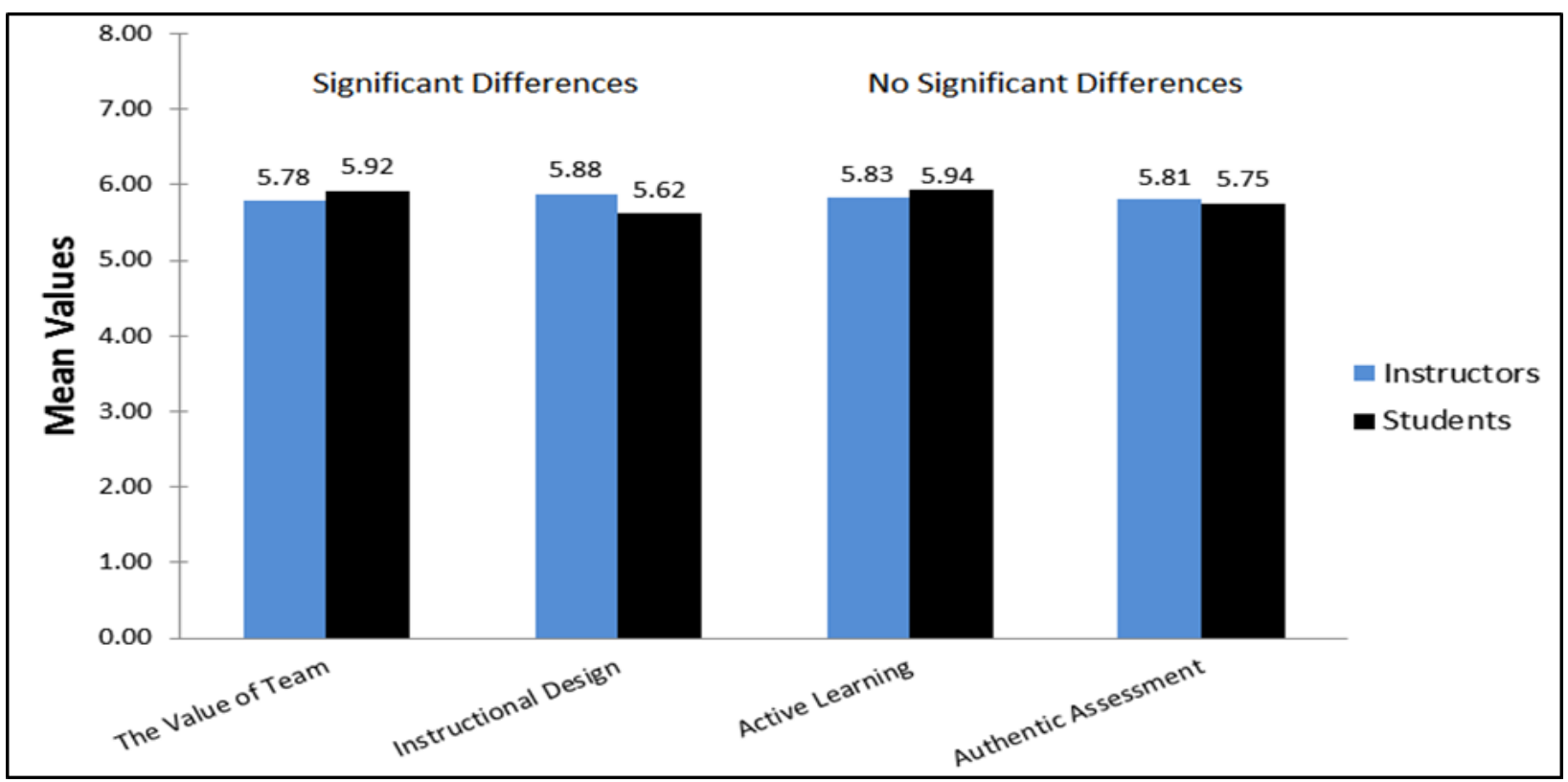

Figure 3: A Chart Of The Mean Values Of Factors Perceived As Important By Instructors And Students

\section{DISCUSSION}

According to the results obtained in this study, instructors and students consider Active Learning as important in TBL. This result is similar to the study of Koles, Nelson, Stolfi, Parmelee, and DeStephen (2005) who demonstrated that TBL and Case-Based Group Discussion (CBGD) are equally effective as active learning strategies. The results of the present study also relate to the results of Vasan, DeFouw, and Holland (2008) who found that a TBL approach in teaching anatomy allowed instructors to create an active learning environment that helped students improve their performance. Furthermore, Nieder, Parmelee, Stolfi, and Hudes (2005) reported that

Team-Based Learning ...is a very "active learning” process that promotes both the learning of factual material as well as higher-level cognitive skills; it uses small groups and requires team members to work collaboratively. (p. 57)

Levine et al. (2004) found that team learning is an instructional strategy that fosters active learning through small-group interaction. According to the National Education Act B.E. 2542 and Amendments (Second National Education Act B.E.2545), active learning is also encouraged to "...provide training in (the) thinking process, management, how to face various situations and application of knowledge for obviating and solving problems" (Office of the National Education Commission 2003, Section 24, p. 11).

Authentic Assessment was identified as important in instructors' and students' perceptions. Such forms of assessment usually include a task for students to perform and a rubric by which their performance on the task is evaluated (Muller, 2011). In authentic assessment, assessment drives the curriculum. That is, teachers first determine 
the tasks that students will perform to demonstrate their mastery, and then a curriculum is developed that will enable students to perform those tasks well and which will include the acquisition of essential knowledge and skills. This approach has been referred to as planning backwards (McDonald, 1992). Wellington, Thomas, Powell, and Clarke (2002) suggested that in authentic assessment strategies, instructors can employ a range of assessment techniques: performance evaluations, criterion referenced appraisals, systematic observations by instructors, peers, self and portfolios and also use the Individual Readiness Assurance Test (I-RAT) from their assignment to check student knowledge. Nider, Parmelee, Stolfi, and Hudes (2005) suggested that, in correlation analysis of TBL and examination performance, individual readiness assurance test performance is a good predictor of examination performance and further, that student performance, TBL may most benefit academically at-risk students who are forced to study more consistently.

The comparison between instructors' and students' perceptions of TBL revealed that students are significantly more likely to favor The Value of Team than Instructional Design. Kirschner, Paas and Kirschner (2009) found that the type of task determines student preference to work in a collaborative or individual manner and that group-based learning can be detrimental in certain situations. For tasks which require memory, students as a group obviously outperformed individual students. When each group member had to recall, however, those who worked alone out performed them all. Therefore, it could be argued that a higher number of retention tasks are suitable for group learning because students can help one another to remember, but they are detrimental for individual development as social loafing can take place. However, Kirschner et al. (2009) suggested that difficult problem-solving tasks assigned to group of students are beneficial for both individual development and group performance because the cognitive load imposed by the problem is shared by members, resulting in the interdependence among team members. In this manner, each student engages in social interaction to collaborate and as such the team can produce more than the sum of its parts. Katzenbach and Smith (1993) found that as a team, students can reach the common goal and responsibility on their own, are interdependent and responsible for working and solving problems together in a team when they are committed to each other to build effectively power to work. Collaborative learning helps students to develop social relationships, social and communication skills, positive attitudes in teams, group cohesion and to solve problems together (Johnson \& Johnson, 1999).

Another intriguing question is why instructors are significantly more likely to favor Instructional Design than The Value of Team. This might be explained by the premise that a TBL instructor is a manager who determines the teams (Michaelsen, 2004). Fink (2004) argued that TBL is “.... a particular instructional strategy that is designed (a) to support the development of high-performance learning teams, and (b) to provide opportunities for these teams to engage in significant learning tasks" (p. 9). Tai and Koh (2008) also suggested that TBL instructors are to help consolidate and help the teams to focus on learning by stimulating an energetic, total-class discussion with teams to form a consensus. Therefore, Nider, Parmalee, Stolfi, \& Hudes (2005) found that TBL helps students understand course content and concepts, makes them study more consistently and encourages interaction, discussion, and problem solving. From this perspective, TBL is under the direct control of instructors. If a task is poorly designed by instructors, it is unlikely that such task will contribute to learning (Sweller, Kirschner, \& Clark, 2007).

\section{CONCLUSIONS AND LIMITATIONS}

The purpose of the study reported on in this paper was to identify and compare instructors' and students' perceptions of TBL in universities in Thailand. The results of the study indicated that both instructors and students perceived Active Learning and an emphasis on Authentic Assessment as important factors. When compared to instructors, students were significantly more likely to value The Value of Team than Instructional Design in TBL. This emphasis on The Value of Team and on the important role of the student in the classroom is congruent with the reforms targeted in Thailand's Education Act. As such, TBL may serve as an effective vehicle in Thailand's universities in helping the country to achieve educational reform and move towards student-centeredness.

The study's context was limited to universities in the metropolitan area of Bangkok in Thailand. The questionnaire was predetermined and the respondents were limited in number. If students and instructors had been given open-ended questions, it is possible that they may have identified a different set of factors as important. The results of the questionnaire were obtained from students in faculties of Industrial Education, but the responses might have been different had students in other faculties been surveyed. 


\section{ACKNOWLEDGEMENTS}

The researchers would like to express a very special thank you for the advice of Professor Dr. Elizabeth Murphy, Dr. Cecile Badenhorst, and Maria A. Rodriguez Manzanares, Faculty of Education, Memorial University, Newfoundland and Labrador, Canada, as well as David Crookall, Universite de Nice Sophia Antipolis, France, and Kenneth Dun, formerly of Assumption University of Thailand, for proofreading and editing this article.

\section{AUTHOR INFORMATION}

Thanongsak Sovajassatakul is a lecturer in the Department of Industrial Education at King Monkut's Institute of Technology, Ladkrabang, Thailand, and a doctoral candidate in the Learning Innovation in Technology Program at King Monkut's University of Technology Thonburi, Thailand. E-mail: ake_tns@hotmail.com

Kalayanee Jitgarun is an Associate Professor in the Department of Electrical Technology Education at King Mongkut's University of Technology Thonburi, Thailand. She has twenty-five years' experience in teaching and conducting research on curriculum and instruction and has authored various publications, most recently on quality assurance in engineering education and vocational education. E-mail: kalayanee.jit@kmutt.ac.th

Raveewan Shinatrakool is an Associate Professor and former dean of the Faculty of Industrial Education, King Monkut's Institute of Technology, Ladkrabang. Presently, she is working as a specialist in the Faculty of Industrial Education, King Mongkut's University of Technology North Bangkok, Thailand. Her main research interests are teaching and learning in information technology. E-mail: sravewan@yahoo.com

\section{REFERENCES}

1. Aggarwal, P., \& O'Brien, C. L. (2008). Social loafing on group projects. Journal of Marketing Education, 30(3), 255-264.

2. Clark M. C., Nguyen H. T., Bray C., Levine R. E., (2008). Team-based learning in an undergraduate nursing course. Nursing Education, 47(3), 111-117.

3. Dana, S. W., (2007). Implementing Team-Based Learning in an Introduction to Law Course, Journal of Legal Studies Education, 24(1), 59-108.

4. Deeter-Schmelz, D. R., Kennedy, K. N., \& Ramsey, R. P. (2002). Enriching our understanding of student team effectiveness. Journal of Marketing Education, 24(2), 114-124.

5. Dunaway, GA. (2005). Adaption of team learning to an introductory graduate pharmacology course. Teach Learn Med, 17(1), 56-62.

6. Fairfield, K. (2003). Tuning into the music of groups: A metaphor for team-based learning in management education. Journal of Management Education, 27(6), 654-672.

7. Fines, G. B., McCabe, S. M., \& Sparrow, S. (2010). Using team-based learning to teach collaborative practice skills. Institute for Law Teaching and Learning Summer Conference June 17-18.

8. Fink, L. D. (2004). Getting started with team-based learning. In L. K. Michaelsen, A. B. Knight, and L. D. Fink (Eds.), Team-based learning: A transformative use of small groups in college teaching (p. 9). Sterling, VA: Stylus Publishing.

9. $\quad$ Frash, Jr. R., Kline, S., \& Stahura, J. (2004). Mitigating social loafing in team-based learning. Journal of Teaching in Travel and Tourism, 3(4), 57-77.

10. Gorsuch, R. L. (1983). Factor analysis. 2nd ed. Hillsdale, NJ: Lawrence Erlbaum Associates.

11. Haidet, P., O’Malley K. J., \& Richards, B. (2002). An initial experience with team learning in medical education. Academic Medicine, 77(1), 40-44.

12. Harman, H. H. (1976). Modern factor analysis. Chicago, IL: University of Chicago Press.

13. Hernandez, S. A. (2002). Team-based learning in a marketing principles course: Cooperative structures that facilitate active learning and higher level thinking. Journal of Marketing Education, 24(1), 45-75.

14. Hunt, D.P., Haidet, P., Coverdale, J.H., \& Richards, B. (2003). The effect of using team learning in an evidenced-based medicine course for medical students. Teach \& Learn in Medicine, 15(2), 131-139.

15. Johnson, D. W., \& Johnson, R. T. (1999). Learning together and alone: Cooperative, competitive, and individualistic learning (5th ed.). Boston: Allyn \& Bacon. 
16. Jamornmarn, U. (1996). Synthesize Process Learning from Thai population, Report research.

17. Jongrungreang, N., \& Vinijkul, S. (2001). The study of the inquiry behavior between the first year to the fourth year of nursing students in Kuakarun Colledge of Nursing. Journal of Nursing Education, 12(2), 4960.

18. Joreskog, K. G., \& Sorbom, D. (1996). LISREL 8: User's reference guide. Chicago: Scientific Software International, Inc.

19. Kaiser, H. F. (1974). An index of factorial simplicity. Psychometrika, 39, 31-36.

20. Katzenbach, J. R., \& Smith, D. K. (1993). The wisdom of teams: Creating the high-performance organization. Boston, MA: Harvard Business School.

21. Kelly, P. A., Haidet, P., Schneider, V., Searle, N. S., Seidel, C., \& Richards, B. F. (2005). A comparison of in-class learner engagement across lecture, problem-based learning, and team learning using the STROBE classroom observation tool. Teaching and Learning in Medicine, 17(2), 112-8.

22. Kirschner, F., Paas, F., \& Kirschner, P. A. (2009). Individual and group-based learning from complex cognitive tasks: Effects on retention and transfer efficiency. Computers in Human Behavior, 25, 306-314.

23. Kline, S., Frash Jr, R. E., \& Stahura, J. M. (2004). Empowering individual effort in cooperative learning. Journal of Hospitality \& Tourism Education, 76(4), 35-43.

24. Koles, P., Nelson, S., Stolfi, A., Parmelee, D., \& DeStephen, D. (2005). Active learning in a year 2 pathology curriculum. Medical Education, 39(10), 1045-1055.

25. Koles, P., Stolfi, A., Borges, N. J., Nelson, S., Parmelee, D. (2010). The impact of team-based learning on medical students' academic performance. Academic Medicine, 85(11), 1739-1745.

26. Levine, R. E., O’ Boyle, M., Haidet, P., Lynn, D., Stone, M. M., Wolf, D. V., \& Paniaqua, A. F. (2004). Transforming a clinical clerkship through team learning. Teaching and Learning in Medicine, 16(3), 270-5.

27. Letassy, A. N., Fugate, E. S., Medina, S. M., Stroup, S. J., \& Britton, L. M. (2008). Instructional Design and Assessment: Using team-based learning in an endocrine module taught across two campuses. American Journal of Pharmaceutical Education, 72(5), 103.

28. McDonald, J. P. (1992). Dilemmas of planning backwards: Rescuing a good idea. Teachers College Record, 94, 152-169.

29. McInerney, M., \& Fink, L. D. (2003). Team-based learning enhances long-term retention and critical thinking in an undergraduate Microbial Physiology course. Journal of Microbiology \& Biology Education, 4: 3-12.

30. Michaelsen, L. K. (2004). Getting started with team-based learning. In L. K. Michaelsen, A. B. Knight, and L. D. Fink (eds.), Team-based learning: A transformative use of small groups in college teaching (pp. 2750). Sterling, VA: Stylus Publishing.

31. Michaelsen, L. K., Knight, A. B., \& Fink, L. D. (eds.) (2004). Team-based learning: A transformative use of small groups in college teaching. Sterling, VA: Stylus Publishing.

32. Mueller, J. (2011). What does authentic assessment look like? From http://jfmueller.faculty.noctrl.edu/toolbox/whatisit.htm

33. Nider, L. G., Parmelee, X. D., Stolfi, A., \& Hudes, D. P. (2005). Team-based learning in a medical gross anatomy and embryology course. Clinical Anatomy, 18, 56-63.

34. Office of Education Council. (2001). Higher educational reform in accordance with the national education act, 1999. Retrieved from http://www.onec.go.th/publication/48033/full48033.pdf

35. Office of the National Education Commission. (2002). National education act B.E. 2542 (A.D. 1999) and Amendments (Second National Education Act B.E.2545 (A.D. 2002)).

36. Office of the National Education Commission. (2003). National education act B.E. 2542 and Amendments (Second National Education Act B.E.2545. Bangkok, Thailand: Office of the National Education Commission.

37. Paulson, R., \& Faust, L. (2000). Active learning for the college classroom. Retrieved from http://www.calstatela/dept/chem/chem2/Active/index.html.

38. Parmelee, D.X., DeStephen, D., \& Borges, N. J. (2009). Medical students' attitudes about team-based learning in a Pre-Clinical Curriculum. Medical Education, Online [serial online] 2009; 14:1 doi;10.3885/meo.2009.Res00280 Available from http://www.med-ed-online.org

39. Polsaram, P. (2001). Development of higher education institutions: Total academic journal. Bangkok: Chulalongkorn University. 
40. Schene, A., Wijngaarden, B., Koeter. M. (1998). Family caregiving in schizophrenia: domains, Distress. Schizophrenia Bulletin, 24(4), 609-618.

41. Sibley, J., \& Parmelee, X. D. (2008). Knowledge Is No Longer Enough: Enhancing professional education with team-based learning. New Directions for Teaching and Learning, 116, 41-53. • DOI: 10.1002/tl.332

42. Su, Y. L. (2004). A study of hospitality students' attitudes toward team-based learning. Program Book \& Exhibit Guide of International CHRIE's 2004 Annual Conference \& Exposition, 148.

43. Sweller, J., Kirschner, P. A., \& Clark, R. E. (2007). Why minimal guidance during instruction does not work: A reply to commentaries. Educational Psychologist, 47, 115-121.

44. Tai, C. B., \& Koh, P. W. (2008). Does team learning motivate students' engagement in an evidence-based medicine course?. Annals Academy of Medicine, 37(12), 1019-1023.

45. Thompson, B. M., Schneider, V. F., Haidet, P., Levine, E. R., McMahon K. K., Perkowsk, C. L., \& Richards, B. F. (2007). Team-based learning at ten medical schools: two years later, Medical Education, $41,250-257$.

46. Thonglert, C. (2007). Professional teachers: The new paradigm of education. p 48.

47. Timothy, A. Brown. (2006). Confirmatory factor analysis for applied research. New York, NY: The Guilford Press.

48. Touchet, K. B., \& Coon, A. K. (2005). A pilot use of team-based learning in Psychiatry resident psychodynamic psychotherapy education. Acad Psychiatry, 29, 293-296. doi: 10.1176/appi.ap.29.3.293

49. Turner, R. C. \& Carlson, L. (2003). Indexes of item-objective congruence for multidimensional Items. International Journal of Testing, 3(2), 163-171.

50. Vasan, S. N., DeFouw, O. D., \& Holland, K. B. (2008). Modified use of team-based learning for effective delivery of medical gross anatomy and embryology. Anatomical Sciences Education Journal, 1(1), 3-9.

51. Warr, P., Cook, J. \& Wall, T. (1979) Scales for the measurement of some work attitudes and aspects of psychological well-being. Journal of Occupational Psychology, 52, 129-148.

52. Wellington, P., Thomas, I., Powell, I., \& Clarke, B. (2002). Authentic assessment applied to engineering and business undergraduate consulting teams. International Journal of Engineering Education, 18(2), 168179.

53. Wolfe, K., \& Gould, R. (2001). Insights on team-based learning. Journal of Hospitality \& Tourism Education, 73(3/4), 87-96.

54. Yaghmaie, F. (2003). Content validity and its estimation. Journal of Medical Education, 3(1), $25-27$. 